\title{
Tales of Seduction, Tales of Violence: Argumentative Strategies before the Basel Marriage Court*
}

\author{
Susanna Burghartz (University of Basel)
}

One of the effects of the Reformation in Basel in 1529 was the establishment of the first Protestant marriage court. The objective of this institution, which consisted of five secular and two ecclesiastical judges, was to do away with existing abuses and vices 'which are abhorrent to Christian valour' and to guarantee a new Christian order, which would contribute 'to increasing the glory of God and cultivating a peaceful Christian communal life' in the realm of matrimony as well. ${ }^{1}$ Marriages had to be performed publicly. Two honourable male witnesses were required in order to demonstrate the validity of a promise of marriage. The Reformation ordinance of 1529 had stipulated that men who had 'deceived women in a seductive manner' without themselves being 'provoked' by the women had to marry them. At the same time daughters, i.e. unmarried women, who 'incited' unmarried men to sleep with them and thus behaved as seductresses lost the usual right to claim compensation for the loss of their virginity other than a payment of 5 shillings. ${ }^{2}$ By the time of the promulgation of the actual marriage court ordinance of 1533, though, the concept of seduction was only being applied to young girls. The 1529 regulation, according to which young men had to marry the young girls they had seduced, was abolished because it had given rise to much 'filth'. The regulation stating that young women who had enticed men into sleeping with them could demand only marginal compensation remained in force, however. This legal situation

\footnotetext{
* For their suggestions and criticisms, I would like to thank Claudia Töngi, the participants in the seminar on 'Court Records as Historical Sources' (summer semester 1996) and the members of the women's and gender history working group on 'Gender in the Early Modern Period: Constructions, Projections, Perspectives' that met from 9 to 11 October 1996 in StuttgartHohenheim. Special thanks go to Ulinka Rublack.

${ }^{1}$ Akten zur Geschichte der Basler Reformation in den Jahren 1519 bis Anfang 1534, ed. P. Roth (Basel, 1937), vol. III, no. 473, p. 383. See further Walther Köhler, Zürcher Ehegericht und Genfer Consistorium (Leipzig, 1932-42), 2 vols.; Thomas Max Safley, 'To Preserve the Marital State: the Basler Ehegericht, 1550-1592', Journal of Family History, 7,2 (1982), 16279, and Let no man put asunder. The Control of Marriage in the German Southwest: a Comparative Study, 1550-1600 (Kirksville, Mo., 1984); Joel F. Harrington, Reordering Marriage and Society in Reformation Germany (Cambridge, 1995).

${ }^{2}$ This sum was minimal when compared with the contemporary discussion of compensation for 'stupration' (rape). See Elisabeth Koch, Maior dignitas est in sexu virili. Das weibliche Geschlecht im Normensystem des 16. Jahrhunderts (Frankfurt/Main, 1991), p. 93.
} 
would remain unchanged for two hundred years and offered men a successful defence which was unavailable to women.

While the concept of female seduction thus became crucial for arguments about the validity of promises of marriage and women's claims to compensation for defloration, the marriage court ordinance took account of violence only in connection with rape. Rape cases were explicitly referred to the criminal courts and the severity of punitive sanctions corresponded to the rarity of such trials. The criminalia, the records of the Basel criminal courts, which survive only in fragments, thus contain few records of rape cases from the early modern period, almost all of them involving very young girls or children.

In contrast to legislation, legal practice, and thus the character of the marriage court itself, changed significantly over the course of the sixteenth century. In its first years the marriage court concentrated on traditional decision-making about the validity of disputed promises of marriage. ${ }^{3}$ During this phase, women could still use the marriage courts to help them assert their own claims. From the second half of the sixteenth century, however, as Safley has shown, ex officio cases came to dominate the courts. ${ }^{4}$ Increasingly it was no longer the parties involved who brought their disputes over promises of marriage or divorce suits before the court, but rather the judicial officer who instituted proceedings for fornication offences, such as marriage promises and impregnation out of wedlock, the failure to maintain a common household or, finally, in the seventeenth century, for premature intercourse, i.e. impregnation before going to the altar. Beginning in the second half of the sixteenth century, and particularly from the mid-seventeenth century onward, the marriage court was being transformed into an instrument of official control in marital matters. It became a place where particular forms of sexuality were defined as fornication and punished rather than where the claims of the parties involved were heard and enforced. Accordingly, from that time onward the marriage court was also no longer an authority women could enlist to enforce their interests; they rarely succeeded in getting the court to decide a disputed promise of marriage in their favour. The marriage court now managed first and foremost to establish a discourse of sin. To this extent Safley's thesis that the interests of the women who appeared in court and those of the marriage court itself exhibit parallel structures is no longer convincing for this period. ${ }^{5}$ At best women tried to assert their interests before a court which now convicted men and women alike of fornication, and to defend their honour using traditional arguments, for example by pointing out that they were not seductresses but had been forced into performing sexual acts against their will.

It was within this restructured institutional framework that men brought forward the argument that they had been 'incited' to commit (sexual) acts, while

\footnotetext{
${ }^{3}$ The extent to which Protestant teachings on marriage remained bound by tradition has been emphasized recently by Harrington, Reordering.

${ }^{4}$ Safley, Let no man, pp. $160 \mathrm{ff}$.

${ }^{5}$ Ibid., p. 179.
} 
women insisted that the men had forced them to submit. Several recent authors have pointed out the extent to which narrative structures and patterns influenced speech about violence in the courtroom. ${ }^{6}$ In her studies of pregnancy suits in eighteenth-century Paris, Arlette Farge found that the women's descriptions of violence during the act of impregnation made it possible for them to tell their stories in the first place. Through these descriptions they could speak of sexuality (and their own desire) without it appearing to be an actual (because voluntary and active) culpable offence. ${ }^{7}$ Men, in contrast, painted themselves as the victims of women, who had been the ones to take the initiative. In order 'to be accepted and rehabilitated within the traditional codes of honour and reputation', men and women had recourse to traditional topoi and narrative patterns. Farge speaks of novel-type plots employed by both parties 'in ways relating to each other like opposite mirror-images'. The objective of a historical reading, in her view, is to unlock the novel and its patterns, not to uncover the involved couples' 'secret', i.e. the 'tone' of the violence described in a given case.

Using three case studies, the following discussion attempts to show that sexual violence was not merely a defence argument women used strategically before the marriage court. David Sabean has recently commented that

current discussions are dominated by the widely held assumption that relations between men and women have always been characterized in some way or other by male aggression in the form of physical force. Too often, however, such an approach radically dehistoricizes violence and reduces it to what Eric Hobsbawm has called 'the eternal struggle of the sexes'. In this fashion, the problem is moved not just out of history but outside culture as well. ${ }^{8}$

In order to historicize sexual violence, we need to describe it as an effect of early modern notions of gender and honour as well as of property and family relations. ${ }^{9}$ The example of the Basel marriage court moreover shows how legal definitions of sexual violence and the situation in the courtroom in addition

\footnotetext{
${ }^{6}$ Margherita Pelaja, 'Praxis und Darstellungsformen sexueller Gewalt im Rom des 19. Jahrhunderts', L'Homme. Zeitschrift für feministische Geschichtsschreibung, 7,2 (1996), 28-42; above all Miranda Chaytor, 'Husband(ry): Narratives of Rape in the Seventeenth Century', Gender and History, 7,3 (1995), 378-407; see also Elizabeth Storr Cohen, 'La verginità perduta: Autorappresentazione di giovane donne nella Roma barocca', Quaderni storici, 67 (1988), 169-91.

7 Arlette Farge, La Vie fragile. Violence, pouvoirs et solidarités à Paris au xviii siècle (Paris, 1986), pp. 37 and 52.

${ }^{8}$ David W. Sabean, Property, Production and Family in Neckarhausen, 1700-1870 (Cambridge, 1990), p. 133.

${ }^{9}$ See, for example, Lyndal Roper, 'Will and Honour: Sex, Words and Power in Augsburg Criminal Trials', in L. Roper, Oedipus and the Devil: Witchcraft, Sexuality and Religion in Early Modern Europe (London and New York, 1994), pp. 53-78; Chaytor, 'Husband(ry)'; Pelaja, 'Praxis und Darstellungsformen'; Koch, Maior dignitas, pp. 105ff; Ulinka Rublack, 'Wench and Maiden: Women, War and the Pictorial Function of the Feminine in German Cities in the Early Modern Period,' History Workshop Journal, 44 (1997), 1-21; Rebekka Habermas, 'Frauen und Männer im Kampf um Leib, Ökonomie und Recht. Zur Beziehung der Geschlechter im Frankfurt der frühen Neuzeit', in Richard van Dülmen (ed.), Dynamik der Tradition. Studien zur historischen Kulturforschung (Frankfurt/Main, 1992), pp. 109-36, 282-8.
} 
generated historically specific perceptions, constructions and ways of speaking about male sexual aggression which in turn shaped its subjective experience.

\section{I: Anna Schultheis and Hans Linck: Will and Honour}

In 1540 Anna Schultheis, a maidservant, of Riehen, a village outside Basel, went before the marriage court and brought the following accusation against her employers' son, Hans Linck, of the same village: ${ }^{10}$ when she was carrying a bundle of grass he came to her and violently tore her bodice;

later he also tried to have his way with her in the barn and force her to commit impurities. She had, however, managed to fend him off two or three times. Finally, though, one evening after she had prepared his mother for bed, when his father was not at home, he came into her chamber, roused her from sleep and asked to marry her. Thus she accepted him, and they promised each other marriage by word and deed. He lay down beside her, slept with her, and she obediently performed her marital duties both then and afterwards, as often as he wished it.

According to her own account Anna had failed to resist Hans's violent advances and thus finally agreed to a sexual relationship with him after obtaining a promise of marriage. Hans, in contrast, turned the question of responsibility on its head and with it the question of the future meaning of this sexual relationship. He admitted to having slept with Anna several times, but emphasized that the initiative had come from her: 'that he had lain beside her several times and given in to his lust, to which the plaintiff had given him cause with her incessant enticements, so that he had no other way of resisting her'. No intentions or promises to marry had ever been exchanged. Anna and Hans thus described their sexuality with the help of a classic pair of images: male violence was juxtaposed with female seduction. ${ }^{11}$ The terms 'seduction' and 'violence', however, set up a significant argumentative framework within which men and women could and had to speak about sexuality during courtship before the marriage courts.

The case of Anna Schultheis and Hans Linck appears to correspond precisely to the pattern elaborated by Farge: Anna recounted Hans's sexual attacks in out-of-the-way places and in the stables, while Hans spoke of his desire, describing it as the result of Anna's provocative behaviour. Anna, however, did not bring suit against him for impregnating her, but rather for breach of promise, a suit which still made sense in the early days of the reformed marriage courts, even when the formal legal conditions for a promise of marriage (the presence of two male witnesses when the promise was made) were not fulfilled. With her description of Hans's assaults at the very beginning of their relationship Anna made it clear that she had not taken the initiative. Accord-

${ }^{10}$ Staatsarchiv Basel-Stadt Gerichtsarchiv U4, fol. 50, 51, 51v, 52v-53, 55v-56, 57, 60v, 65.

${ }^{11}$ See also Anke Meyer-Knees, Verführung und sexuelle Gewalt. Untersuchungen zum medizinischen und juristischen Diskurs im 18. Jahrhundert, Probleme der Semiotik 12 (Tübingen, 1992). 
ingly she did not fall under the regulation of the new marriage court ordinance, which did not permit a young woman to sue for the fulfilment of a promise to marry if she had previously 'with entreaties, letters or direct demands herself incited the young man to attach himself to her and lie with her' ${ }^{12}$ Later in the trial Anna said that she had regarded the act of intercourse with Hans after his promise of marriage to fulfil her wifely duty of obedience. In saying this she was still arguing within the prevailing categories of marriage by mutual consent (Konsensehe). Her marital obedience could serve as proof of the existence of a valid promise of marriage, on the basis of which Anna and Hans could be regarded as legitimately wed, even if they did not fulfil the new formal criterion for a valid promise of marriage (i.e. the presence of witnesses). Hans, in contrast, attempted to use the new legal situation by invoking the seduction argument. He admitted that he had slept with the plaintiff, but denied that marriage had ever been mentioned. Rather, he had lain with her several times and indulged his lust because the plaintiff in question had given him cause to do so through constant provocations, leaving him no choice in the matter. ${ }^{13} \mathrm{He}$ thus sought to defend himself against Anna's legal claims by portraying her as a seductress. He stuck to this version throughout the trial as did his father who (also in keeping with marriage law) had threatened to disinherit him. All of the witnesses called, however, believed that a valid promise of marriage had existed between the two, i.e. that Anna, as they put it, 'was not his whore, but rather his wife'. ${ }^{14}$ The court adopted this version and thus the perceptions and terminology about which there was general agreement in the village, with the exception of amongst Hans Linck's family. It is interesting in this context that Hans used seduction as an argument, but that despite the support of his father and the law he had little success in convincing either the village or the court of his standpoint. As long as the Basel marriage court continued to decide cases on the basis of the canonical rules of marriage by mutual consent and did not yet fully apply in practice its own new formal norms on the validity of promises to marry, the argument that men had used force retained an immediate legal relevance: it lifted responsibility from the woman and allowed her to sue for the fulfilment of a promise of marriage. ${ }^{15}$

Violence and seduction were not merely relevant for the clarification of legal claims; they also corresponded to a broader contemporary pair of concepts which had a great impact on perceptions of male and female sexuality: male will and female honour. Writing about sixteenth-century Augsburg, Lyndal Roper has emphasized that these themes point to a fundamental gender asym-

${ }^{12}$ Akten zur Geschichte der Basler Reformation, vol. III, p. 397.

${ }^{13}$ Staatsarchiv Basel-Stadt Gerichtsarchiv U4, fol. 50, 51, 51v, 52v-53, 55v-56, 57, 60v, 65.

${ }^{14}$ Staatsarchiv Basel-Stadt Gerichtsarchiv Uf 1, fol. 104-6, 122-3.

${ }^{15}$ Susanna Burghartz, 'Geschlecht-Körper-Ehre. Überlegungen zur weiblichen Ehre in der frühen Neuzeit am Beispiel der Basler Ehegerichtsprotokolle', in Klaus Schreiner and Gerd Schwerhoff (eds.), Verletzte Ehre. Ehrkonflikte in Gesellschaften des Mittelalters und der Frühen Neuzeit (Cologne, 1995), pp. 214-34. 
metry because 'only a man's will could be "done": a man could not submit to or do a woman's will'. ${ }^{16}$ According to Anna's account Hans, too, had demanded that she 'gratify his will'. Hans, however, claimed that the will involved had been not his own but that of the seductress Anna. With the aid of the concept of seduction-which also corresponded to the characterization of women as the more lustful sex-he tried to avoid the legal consequences that arose from the conceptualization of male sexuality as the superior expression of male will. While Anna thus used the violence argument to counter the concept of lustful female nature, which found concrete expression in the figure of the seductress, Hans for his part used the seduction argument to counter the attribution of rationality and hence responsibility to masculinity. Within the conceptual world of marriage by mutual consent, the idea of will continued to possess very concrete legal significance. In 1540, Anna and those around her still acted within this mental world. When she agreed to a relationship with Hans Linck it was also on the assumption that he, too, shared these notions:

... the said Hans Linck took her in marriage at the Speckbaum [toponym] in the claypit, took a penny from her purse as earnest, and although he had wanted to pull her down and throw her onto the grass that she had been carrying on her head, she had managed to get away from him that time after all. But shortly thereafter he had come to her bed and, by force of the marriage he had promised to her, [said] she should let him lie with her, for she was his, thus he was treating her justly, like a wife. ${ }^{17}$

Anna Schultheis had made this statement to the pastor of Riehen, who had interrogated her together with two justiciaries (Bannherren) and now appeared in court as a witness.

Anna Schultheis's description of her relationship with Linck, which began with a scene of violence, points not only to a tactically deployed court-room strategy intended to play on culturally entrenched images of masculinity and femininity. Like countless similar cases, it also addresses the self-evident violence that prevailed in relations between young men and women during the phase of getting acquainted, as well as the apparently unproblematic combination of the use of force with intentions of marriage. This phenomenon has already been described for various European societies at this period. Guido Ruggiero, for example, has noted that in fifteenth-century Venice rape could be regarded as a part of courtship, particularly among the lower social classes. ${ }^{18}$ Silke Götsch, writing about Schleswig-Holstein in the eighteenth century, has pointed to the limited scope of action available to young women within the system of honour, the speed with which women put their reputations at risk when they gave in to sexual advances, the danger of ruining their chances in the marriage market by acting too aloof, and the acceptance, or even encouragement, of sexual assault and violence towards women of lower rank working in

${ }^{16}$ Roper, 'Will and Honour', p. 60.

${ }^{17}$ Staatsarchiv Basel-Stadt Gerichtsarchiv Uf 1, fol. 105.

${ }^{18}$ Guido Ruggiero, The Boundaries of Eros: Sex, Crime and Sexuality in Renaissance Venice (Oxford and New York, 1985), pp. 101, 156. 
dependent positions. ${ }^{19}$ As a maidservant employed by Hans Linck's parents Anna was subjected to the son's assaults not only in out-of-the-way places but also in the stables and in her own room. Hans took advantage of the situation to have his way one night when Anna had just prepared his mother for bed and his father was out of the house. In Anna's case, however, which occurred at the beginning of the sixteenth century, neighbourhood and village control still functioned to such an extent that her behaviour did not ultimately damage her honour.

Violence as a violation of personal integrity was never at the forefront of interest in this case, either for the participants, the witnesses, or the court authorities. Violence was mentioned because it pointed to something else that was important for evaluating the case. It is precisely in its self-evidence that sexual violence appears normal, accepted, and thus presumably also unproblematic, a part of 'the eternal struggle of the sexes'. Yet it would be hasty to conclude that the women involved themselves experienced this very common violence as unproblematic.

\section{II: Maria Verborgen and Hans Jacob von Brun: Honour and Physical Integrity}

The case of Maria Verborgen and Hans Jacob von Brun from the end of the sixteenth century also involved a socially unequal pair who confronted each other in court with the argument of violence versus seduction, or at least willing consent. In 1588 Maria Verborgen brought suit against Hans Jacob von Brun, citizen of Basel, for having taken her honour by force. ${ }^{20} \mathrm{He}$ had summoned her to meet him in a garden. Expecting no evil intentions, she had gone to the appointment, where, despite her vigorous resistance, he had forced her to have sexual intercourse with him. Maria Verborgen and her father demanded compensation in the form of marriage, explicitly citing imperial law and Exodus 22:16 and thus the legal principle that a man who transgressed against a chaste virgin was compelled to marry her. From their perspective this represented a case of 'stupration', an offence that the Basel marriage court ordinance actually no longer provided for in this form. ${ }^{21}$ Hans Jacob referred to this ordinance in his reply and also explained that Maria had by no means resisted his advances; she had come to the garden of her own free will, and it was she who had pursued him rather than the other way around. Up until this point the case followed the classical patterns of argumentation. Maria, however, gave then her account of the attack, and cited details which open a window onto its psychological effect on her. In his reply, Hans Jacob tried to minimize the extent of the violence used and at the same time to raise the demands made

${ }^{19}$ Silke Götsch, 'Weibliche Erfahrungen um Körperlichkeit und Sexualität nach archivalischen Quellen aus Schleswig-Holstein 1700-1850,' Kieler Blätter zur Volkskunde, 18 (1986), 29-59.

${ }^{20}$ Staatsarchiv Basel-Stadt Gerichtsarchiv U7, fol. $129 \mathrm{v}-133$.

${ }^{21}$ On this change in the law, see above. 
on the woman's resistance. He also cast doubt on her reputation. Central to his defence strategy was the claim that Maria had been a willing participant. She had pursued him, and 'offered incitements', had come to the garden voluntarily instead of remaining at home and, contrary to her account, had not been locked in the garden, but rather had had the key to the garden gate 'in her bag once again before they had had relations with each other'. She thus could easily have left the garden if she wished, but instead had come to him again and sat with him in the garden house for a long while. Thus Hans Jacob decided that 'it had been her will much more than his own'. He did not deny that sexual intercourse had occurred, and in the course of interrogation admitted that he 'had found her as a virgin', but later, in a plain attempt to avoid paying substantial compensation, claimed that he 'could not know whether he had been the first, and would not swear to it'. He made no further response to Maria's concrete accounts of the alleged violence he had used against her in the garden. Of central importance to Hans Jacob was that he had made no valid promise of marriage, and that he was thus free to wed another woman. Apparently he was already involved in marriage negotiations with a woman of much higher social rank whom he later actually married. Violence was not at issue for him: if he had used force, Maria had, according to his account, at any rate submitted willingly to it. He expressly denied having deployed any juridically relevant violence within the meaning of the section on rape in the Carolina: neither was he certain that she had been a virgin, nor had he truly acted against her will, a will that she could and should have expressed in a legally unambiguous manner by screaming (and staying at home).

Maria, in contrast, gave a comparatively detailed account of the violence done to her by Hans Jacob. She vividly described her hopeless situation in the garden: according to her story, he had dragged her in and immediately locked the gate, which could only be opened, from both inside and out, with a key. When she saw that she was trapped and thus at Hans Jacob's mercy she had nevertheless resisted, refusing to sit beside him on the grass and instead clinging to a rope. Her struggle so exhausted her that she had eventually given up, or, as she put it, 'had worked so hard, that she could [deleted: would] no longer fend him off'. At that point Hans Jacob had pulled her to the ground and taken her honour, 'for which she was sorely ashamed'. This shame referred primarily to the consequences of his behaviour for her honour, since shame and honour were closely allied. Maria's further testimony nevertheless makes this case and her own argumentation appear more complex and provides at least hints of the psychological dimensions that the experience of violence must have had for her. In a further description of the garden episode she stated that Hans Jacob had so frightened her that she had no longer been capable of defending herself, and that he had chased her so hard that her legs were covered in nettle stings such 'that it was a disgrace'. The nettle stings may be read here both as an expression of disgrace, which became manifested in a physical sign and were thus visible to all, and as a displaced account of the physical pain and injury 
that she had suffered in the garden. The following statement indicates how complex the emotional relationship between Hans Jacob and Maria may have been: once before Maria had screamed to defend herself when Hans Jacob 'grabbed her under her clothes'. He had then asked her to forgive him and promised 'that he would never do it again as long as he lived'. It was for this reason that Maria had gone to meet him in the garden because, as she said, she had not thought him capable 'of such evil and maliciousness as he had subjected her to'. A further episode which Maria related to the court indicates once again the violence of their relations and at the same time shows the symbolic and thus complex meaning of this violence. After deflowering Maria and, according to her account, promising 'to restore her honour', Hans Jacob encountered her in the house of the mayor. He grabbed her by the hair but, as she reported, she managed to escape him this time by cutting off her plaits with a knife. Not only does her behaviour appear extreme and her willingness to change her own appearance remarkable, but in taking this step Maria also destroyed a sign that marked her membership of the group of virgins, who were allowed to and did wear their hair in plaits. She thus not merely resisted further sexual acts or even violence on Hans Jacob's part, but also re-enacted what had happened to her in the garden — the loss of her virginity — on a symbolic external level.

By invoking the images of the nettle stings and the cut-off plaits, but also by describing her captivity in the garden, Maria Verborgen spoke quite clearly of her fears and, in a displaced manner, also of the physical and mental injuries she had suffered; nonetheless here, too, the legal conflict focused not on sexual violence but on the woman's lost honour. According to Hans Jacob von Brun's testimony, Maria mainly wanted to avoid disgrace. This wish, completely in keeping with the logic of the (female) code of honour, placed her in an even more complex emotional dependency on the man who in her own eyes had raped and disgraced her. Only marriage to him could wholly undo the damage. This dependency caused Maria to make an even more extreme offer of subservience: ${ }^{22}$ she suggested that he could 'keep her not like a wife, but only like a maidservant'. The clerk of the court added maliciously: 'this with crocodile tears'. Although this remark underlined the staged quality of Maria Verborgen's testimony, in this case the court saw more than the dramatic performance of a licentious young woman. The final verdict demonstrated that a potential rape trial had been turned into a suit for breach of promise, in which Maria however did not fully succeed in asserting her case. The court declared the promise of

${ }^{22}$ The structurally even more dependent situation of victims of domestic sexual violence, which led to an almost complete taboo, has been described by Ulinka Rublack in "Viehisch, frech vnd onverschämpt'. Inzest in Südwestdeutschland, ca. 1530-1700”, in Otto Ulbricht (ed.), Von Huren und Rabenmüttern. Weibliche Kriminalität in der Frühen Neuzeit (Cologne, 1995), pp. 171-213. In this context it is remarkable above all that harsher punishments meant 'that in families incest had to be lived with ...' (p. 205). Put another way, in this case it was the criminal justice system that promoted violence within the family by preventing it from being addressed. 
marriage invalid and sentenced both parties to imprisonment in a tower for fornication. Hans Jacob von Brun, at least, was ordered not merely to pay an unusually high fine of 50 talers plus the costs of the birth and rearing the child, but also to make an unusually high compensation payment of 100 gulden to Maria Verborgen. It is even more remarkable that the trial resulted in an extremely unusual minority vote. Two of the judges wanted to declare the promise of marriage valid and force Hans Jacob to take Maria to the altar. They were prepared in this case to accept the Mosaic injunction adopted in the original Reformation ordinance of 1529 , according to which a man had to marry a woman whom he had 'deceived in a seductive manner' - a regulation that, as mentioned above, had already been removed from the marriage court ordinance of 1533 . We can only guess at the reasons for this willingness; they may have included the bad reputation of Hans Jacob and his brothers, and also the violence he employed. The majority, however, voted for the solution of a compensation payment. ${ }^{23}$ By imposing a payment of 100 gulden on Hans Jacob the court implicitly labelled him a seducer, thus accepting Maria's version of events, according to which he had used violence to force her into sexual intercourse. The payment was not, however, made as satisfaction or damages for the violence she had suffered, but as compensation for the loss of her sexual integrity. ${ }^{24}$

\section{III: Anna Schwingdenhammer and Jacob Schlosser: Trauma and Taboo}

In the cases discussed above women used the violence they had suffered as an argument for securing a promise of marriage or marriage itself. By using the defence of violence women sought to free themselves of the charge of seduction, a behaviour that would have cost them any legal right to compensation from the man involved. At the same time, the account of violence emphasized the man's will: he was responsible for the sexual act and was thus expected to face up to his responsibility and the consequences of his actions.

During the trial heard by the marriage court in 1650, Anna Schwingdenhammer used the violence argument differently. ${ }^{25}$ She had no desire to marry Jacob and thus did not need to prove that she had not seduced him. While in this case Jacob Schlosser insisted that he was prepared to fulfil a supposedly valid promise of marriage by taking Anna to the altar, Anna was concerned to assert her own wishes against those of Jacob and her parents. She thus tried

\footnotetext{
${ }^{23}$ Canon law (X.5.16.1) had already designated marriage or compensation (ducat aut dolet) as the legal consequences of the crime of 'stupration'.

${ }^{24}$ On the legal background to the discussion on stuprum, see Koch, Maior Dignitas, pp. 92ff, particularly pp. 95-6. The fact that not only the stuprator but also his victim received a sentence for fornication shows how dominant the fornication discourse had already become in late sixteenth-century Basel.

${ }^{25}$ Staatsarchiv Basel-Stadt Gerichtsarchiv U 30a, 20 June to 12 September 1650.
} 
to refute the man's argument that she had agreed to marry him by invoking the violence argument. In a certain sense the roles in this case were reversed: it was not the woman's sexual honour that was at stake, for a change, but rather her will. In the course of the trial it became increasingly apparent that Anna was even prepared to risk damaging her sexual reputation in order to assert her will. The Schlosser-Schwingdenhammer trial was atypical of cases heard before the marriage court in another respect as well. Rarely were references to force and threats of force made on so many levels during a trial. In addition, this trial made it particularly clear that women's identity, even when they used violence as an argument in the courtroom, was indeed affected and injured by the violence they suffered, and that a strategic use of the violence argument in court by no means indicated that women had consented to, accepted or successfully processed their experiences of violence. On 20 June 1650 the clerk of the court opened ex officio proceedings against Jacob Schlosser and Anna Schwingdenhammer: they had become betrothed but had not solemnized the marriage, and he wished to be informed of the true state of affairs. ${ }^{26}$ The horse-collar maker Jacob Schlosser explained that approximately one year previously he had conceived an inclination [Lust und Liebe] towards Anna, had spoken to her about the possibility of marriage, presented her with stockings as pledges of conjugal love and, on the condition that her parents were agreeable, continued to court her. An initial meeting to make betrothal arrangements (Ehetag) had been unsuccessful because of some point not mentioned in the records, but shortly thereafter they had repeated and affirmed their espousals. Now, however, Anna was trying to withdraw. Jacob demanded to know what her misgivings were, whether she harboured some objection to his origins or his trade. Anna's lawyer explained that she had no objections regarding his honour, but that she had never had any inclination towards him (in legal terms this meant that she had never agreed to his promise of marriage) and was also still a minor. Thus the central points (which were, however, only partly in dispute) introduced early in the trial were the woman's consent ('inclination towards him'), the consent of her parents, whether she was of age to marry, and the man's honour. After a further exchange of arguments between the parties Anna was examined alone by the court. She declared that she had not agreed in any form, either verbal or non-verbal, to the marriage; she had only spoken to Jacob at her parents' bidding, and far from accepting his gifts, she had flung them to the ground. The report of her testimony ended with the words, 'Father and Mother were at fault for everything, they forced her. She desired no one, neither him nor anyone else. She could not stay with him nor love him. She would rather die.' Anna clearly did not wish to be married off by her parents against her will. The extreme manner in which she

\footnotetext{
${ }^{26}$ Whether the action taken by the marriage court may be attributed to Schlosser's initiative can no longer be determined with certainty, although the later course taken by the trial would seem to favour this assumption.
} 
phrased her disinclination is striking: she did not want this man or any other; she would rather die than marry. Such a statement, with its clearly self-destructive potential, was unusual before a marriage court, and it accordingly captured the court's attention, although at that point the motivation behind it was not yet clear. At the beginning of the legal proceedings it had appeared that the court was faced with a normal case of courtship and betrothal: words and gifts had been exchanged, at least one meeting to make betrothal arrangements had taken place, and the woman's parents were informed and had given their consent. Only the young woman's consent was in dispute.

The trial continued with Anna's written statement of defence. Her lawyer took up where the previous day of the trial had left off, following his statement with a plea from Anna's parents 'to proceed with a separation; otherwise there could be danger to life and limb'. Once again the urgent peril that loomed if Anna were forced to marry Jacob was emphasized. This time, though, no reason for such a danger was mentioned. Rather, Anna's parents stressed their basic consent to the marriage, which was shaken only by their inability to convince their daughter to agree to it. Anna reaffirmed her aversion to the planned marriage, asserting that 'she had believed she must obey her parents, but she could have no love for him, did not want to take him no matter what was done to her. She did not care even if she was forbidden from taking another man for eight or ten years.' The young woman was thus prepared to risk her chances in the marriage market; she would rather accept a ban on marrying for eight or ten years than take Jacob Schlosser as her husband. Anna insisted on her opposition so vehemently that her parents now regarded the marriage, to which they had initially agreed, as a serious danger to their daughter's life. Jacob, however, insisted that this betrothal was binding, for he regarded the breach of promise as a threat to his reputation. At a wedding party the other men who danced with Anna had insulted him, calling him a 'churlish fellow' and casting doubt on his honour as a journeyman. The court decided to attempt an amicable settlement. This settlement did not come about and Jacob continued to insist upon his right to a solemnization of the marriage. Anna's lawyer explained that she was still a minor and had not known what she was doing. Jacob, in contrast, insisted that the parents had given their consent, and that Anna had spent 'many a night at his side and sat on his lap'. By describing the relationship between himself and Anna as intimate and thus also sexual, he implicitly touched on both her alleged consent and her honour. Without an intention to marry Anna's behaviour as described would already have been perilously close to fornication. In the subsequent confrontation, in which Anna denied Jacob's assertions, he gave a more precise description, saying 'that she had sat on his lap in the forge on her father's anvil-block'. Jacob continued to pursue this dual strategy, on the one hand using the alleged existence of a sexual relationship to underline Anna's consent and on the other compromising her reputation if she continued to refuse to marry him. On the next day in court he stated explicitly that he had "laid her down, putting a large hammer and his coat under her 
head. He touched her everywhere and she had willingly allowed him to do so. But no fornication took place.' Here he brought in a further term that was central to discourse before the court: fornication. Jacob was attempting to make use of the dominant interest of the juridical discourse on sin: the prosecution of fornicators. As in the Verborgen-von Brun case, the court's discourse on fornication became a further significant factor in the framework of conditions within which the participants had to act and argue. By invoking the threat of prosecution for fornication and the accompanying damage to her honour, Jacob sought to confront Anna with a dilemma that she could escape only by marrying him. The interests of the woman appear to have become caught between the interests of the man and the court. After a further confrontation between the two parties, in a logically consistent step the court suggested to the parents that, given the state of affairs, they should endeavour to marry their daughter to Jacob Schlosser. But the parents restated their clear opposition to Jacob's intentions; they vehemently rejected any suspicion of fornication, arguing that he had threatened 'that if he could not have her he would find a way to bring disgrace upon her'. Once again they made an urgent plea for a separation, 'lest something more terrible arise, such that one could only throw up one's hands in despair'. Thus the threats and counter-threats escalated. In the next session of the court Jacob demanded that the court order the solemnization of the marriage. After a further exchange of words with the defendant he offered to swear under oath that 'she had accepted his marriage proposal'. Anna's father, Heinrich Schwingdenhammer, was also compelled to reconfirm that he had consented to the marriage. It seemed certain that the court would declare the betrothal valid, force Anna to marry Jacob, and order a solemnization of the marriage. In this situation Anna's lawyer introduced a reversal in the proceedings by explicitly declaring that Jacob had done violence to Anna: 'the plaintiff tied her hands in the forge so that he could fondle her'. The court immediately suspected fornication and questioned Jacob, who continued to insist on Anna's consent and who now admitted that they had had intercourse one single time in the forge. Once again it becomes evident that the court had no interest in violence as the violation of personal integrity. Instead, its primary focus was on the issue of fornication and only then on the issue of consent (i.e. will) and perhaps also the problem of seduction. Anna immediately denied any sexual intercourse with Jacob and compared her situation to that of the biblical Susannah, who had also been subject to the false witness of two judges. The court adjourned with the decision that 'the parents should call in some female persons from among their friends and relations who are to sound out the daughter and discover whether or not congress took place'. In the following eighth day of the proceedings Anna's parents recounted how they, 'together with an honest kinswoman', had questioned their daughter between one and six o'clock. Their daughter had finally made the following confession:

he had laid her down on the anvil-block, held her hands against her head and believed that he would accomplish the deed. This did not happen, however, for she emerged as 
pure as from her mother's body. He had also bound her hands together on a previous occasion. Ever since lying on the anvil-block she had conceived such an aversion to him that she could no longer look upon him.

Now the daughter's categorical refusal and the dark threats of danger to life and limb if the betrothal was not dissolved became more understandable. Anna depicted herself as a victim of Jacob's sexual violence who, traumatized by the experience, had made the central event in the case taboo and long remained silent about it in court. According to her own testimony the events in her father's forge were at the root of her aversion to Jacob. Jacob, in contrast, continued even now to insist that Anna had been a willing participant, but he now took back his assertion that the sexual act had been consummated:

he had lain on the bed with her twice, but had not committed fornication with her. On the anvil-block, however, she had given her consent; he had lain down upon her and touched her body, and the substance had passed out of him. He could not say, though, whether the substance had entered her body; he also could not say that he had taken her virginity.

At the same time he no longer insisted on asserting his right to marry Anna, but rather left it up to the court to decide. In a final round of questioning Anna emphasized once again that 'she had never encouraged his wantonness' and could not marry him, while Jacob declared that he could not claim 'to have robbed her of her virginity'. Thanks to these declarations Anna succeeding in having her way without losing her sexual honour. Here once again we see the narrowness of the scope of action that was available to young women, and which Anna was able this time to use to her own ends. The court came to the conclusion that the promise of marriage was void because the woman was a minor and had failed to give her consent. The verdict also mentioned other 'serious reasons' which were not, however, explicitly named. This formulation presumably referred to Jacob Schlosser's use of violence, an offence whose tabooing meant that it was not mentioned explicitly even in the verdict. Fines were imposed on all of the main participants: on the parents for violating the marriage court ordinance, which stated that parents should not force their children to marry, on the daughter for 'immodest behaviour', and on Jacob Schlosser because he 'had obstructed the court and taken the wrong path by telling untruths'. The court also imposed a one-year marriage ban on Anna, while Jacob was awarded compensation for his costs. This last stipulation opened up a new field of conflict: after failing in his attempt to marry Anna and thus gain definitive access to her body, Jacob had at least tried to gain access to as much of Heinrich Schwingdenhammer's money as possible and thus attain material compensation. In these efforts, too, he was only partly successful.

The case of Schlosser versus Schwingdenhammer, like that of Linck versus Schultheis, revolved around will and honour, although in the former case it was the woman's will that was at issue. In both cases violence was mentioned very early on in the trial. The case of Anna Schwingdenhammer and Jacob 
Schlosser differed from the other cases, though, in that violence was first addressed in a self-destructive form. What was at issue here was not sexual violence, but marriage as a danger to the life of the defendant. The reference to a death wish and mortal danger at the beginning of the trial was highly unusual. The explicit and implicit meanings of this way of speaking serve several indicatory functions throughout the proceedings. First of all, they accentuate the strategic manner in which the trial's participants dealt with both the violence argument more generally (danger to life and limb, etc.), and sexual violence, which was introduced as an argument much later in the trial and then initiated the decisive turning point in the proceedings. Beyond that, the explicit reference to violence suggests a more psychological reading. In this interpretation the defendant's self-destructive wishes become visible as a semantic displacement that refers to the central problem of traumatization through sexual violence without having to name it explicitly. For Anna, this traumatization resulted in a taboo on speaking of her experiences of violence. Remarkably, the court duplicated this tabooing of sexual violence by explicitly not including it in the reasons for its judgment, choosing instead a circumlocutory formulation. Finally, the indicatory functions of the verbal references serve a channelling function for the textual interpretation itself, allowing formulations which are at first bewildering to be placed in a context of meaning during the trial, thus drawing the reader's particular attention to the scene of violence.

The material provided by these cases makes it clear that even in a society that considered sexual violence, violence between the sexes, and violence more generally to be normal everyday phenomena, ${ }^{27}$ psychic injuries could occur that made it difficult or impossible to speak about violence. Thus the (omni)presence and normality of violence between the sexes by no means necessarily renders such violence unproblematic for the identity of its victims. It was precisely the close association between female honour and female identity that promoted the tabooing of experiences of violence-a connection recently and vividly invoked by Miranda Chaytor. ${ }^{28}$ At the same time, it was this very connection that permitted violence to be addressed within the context of the seduction argument, and that thus opened up a narrative scope, albeit narrow. ${ }^{29}$ It is also quite clear that the instrumental, argumentative approach to violent experiences in court cannot merely be played off against the assumption of psychic damage or traumatization. Here, in turn, the argumentative framework set up by marriage law and the marriage courts comes into play. In the courtroom, sexual violence between unmarried people could be

\footnotetext{
${ }^{27}$ Violence by men against women was also normal in the sense that, when applied 'in moderation', it explicitly conformed to the norm as represented, for example, in treatises on marriage and educational works.

${ }^{28}$ Chaytor, 'Husband(ry)', pp. 396ff.

${ }^{29}$ The possibility of agency in narratives of rape is discussed in Garthine Walker, 'Rereading Rape and Sexual Violence in Early Modern England', Gender and History, 10, 1 (1998), 1-25, esp. pp. 19f. See also Ulinka Rublack's introduction to this issue, above.
} 
addressed only within the context of will and seduction. Reference to this form of violence between the sexes thus always had a strategic function within a trial, given that such violence had no place there as a criminal offence in its own right. Sexual violence had no juridical significance if the woman had already given her consent to sexual intercourse.

Paradoxically it was within the framework of such strategic arguments about consent and not in rape accusations, which were legally made impossible, that women could relate, to some extent, how they had experienced male violence and the shame and harm they had suffered.

Translated by Pamela Selwyn 